\title{
Role of D2 dopamine receptor in adrenal cortical cell proliferation and aldosterone-producing adenoma tumorigenesis
}

\author{
Hong-Wei Chang, Chao-Yuan Huang', Shao-Yu Yang, Vin-Cent Wu, Tzong-Shinn Chu, \\ Yung-Ming Chen, Bor-Shen Hsieh and Kwan-Dun Wu
}

Nephrology Division, Department of Internal Medicine, Room 1419, National Taiwan University Hospital, Clinical Research Building, 7 Chung-Sun South Road, Taipei 100, Taiwan

${ }^{1}$ Department of Urology, National Taiwan University Hospital, Taipei, Taiwan
Correspondence should be addressed to K-D Wu

Email

kdwu@ntuh.gov.tw

\begin{abstract}
Aldosterone-producing adenoma (APA) and bilateral adrenal hyperplasia are the two characteristic types of primary aldosteronism. Dysregulation of adrenal cortical cell proliferation contributes to both diseases. We previously demonstrated that APA expressed less dopamine $\mathrm{D} 2$ receptor than the respective non-tumor tissue and might contribute to the overproduction of aldosterone. As activation of D2 receptor inhibits the proliferation of various cells, downregulation of D2 receptor in APA may play a role in the tumorigenesis of APA. In this study, we demonstrate that D2 receptor plays a role in angiotensin II (AII)stimulated adrenal cortical cell proliferation. The D2 receptor agonist, bromocriptine, inhibited All-stimulated cell proliferation in primary cultures of the normal human adrenal cortex and APA through attenuating All-induced phosphorylation of PK-stimulated cyclin D1 protein expression and cell proliferation. D2 receptor also inhibited All-induced ERK1/2 phosphorylation. Our results demonstrate that, in addition to inhibiting aldosterone synthesis/production, D2 receptor exerts an anti-proliferative effect in adrenal cortical and APA cells by attenuating PKC $\mu$ and ERK phosphorylation. The lower level of expression of D2 receptor in APA may augment cell proliferation and plays a crucial role in the tumorigenesis of APA. Our novel finding suggests a new therapeutic target for primary aldosteronism.
\end{abstract}
Key Words
- dopamine receptor
- aldosterone-producing adenoma
- protein kinase C
- cell proliferation

Journal of Molecular

Endocrinology

(2014) 52, 87-96

\section{Introduction}

There is growing evidence that the prevalence of primary aldosteronism is much higher than previously thought (Rossi et al. 2006). The two main subtypes of primary aldosteronism are bilateral adrenal hyperplasia and aldosterone-producing adenoma (APA). The pathogenesis of both diseases involves the over-proliferation of adrenal cortical cells. However, the molecular mechanism remains unclear. Although angiotensin II (AII) stimulates aldosterone production through the angiotensin type 1 receptor (AT1R), its effect on the proliferation of the aldosterone-producing cells is controversial (McEwan et al. 1990, Mazocchi et al. 1997, Otis et al. 2004, 2005). There was no difference in the level of AT1R between APA and the non-tumorous part of the adrenal (Chang et al. 2007), and a linkage study failed to demonstrate a role of AT1R in the pathogenesis of primary aldosteronism (Torpy \& 
Stratakis 1998). Recently, we demonstrated that the downregulation of dopamine D2 receptor (DRD2) in APA contributed to the increased CYP11B2 mRNA and aldosterone over-production through enhancing PKC $\mu$ activation (Chang et al. 2007). This finding indicates that the DRD2 plays an important role in the pathogenesis of primary aldosteronism.

Many studies have shown a role of DRD2 in cell proliferation. Activation of DRD2 inhibited proliferation of various cells, such as forebrain neural stem cells, vascular endothelial cells, colon epithelial cells, and lactotrophs (Saiardi et al. 1997, Gemignani et al. 2005, Campa et al. 2007). Transgenic knockout of DRD2 in mice resulted in hyperprolactinemia and prolactinoma (Kelly et al. 1997, Saiardi et al. 1997). In human studies polymorphisms of dopamine receptors are associated with the risk of colorectal cancer (Gemignani et al. 2005) and lung cancer (Campa et al. 2007).

The effect of DRD2 on AII-stimulated aldosterone synthesis/secretion of H295R cells, a human adrenal cortical carcinoma cell line, is mediated via inhibition of the phosphorylation of PKC $\mu$ (Chang et al. 2007). РKC $\mu$ and its mouse homolog PKD, a serine/threonine protein kinase, have been implicated in diverse cell functions including immune response, apoptosis/cell proliferation, and tumor metastasis (Rykx et al. 2003, Wang 2006). As activation of D2 receptors may inhibit cell proliferation via inhibition of AII-stimulated phosphorylation of $\mathrm{PKC} \mu$, we developed the hypothesis that downregulation of D2 receptors in APAs plays a role in their tumorigenesis.

\section{Subjects and methods}

\section{Patients and tissue samples}

The diagnosis of APA was established by clinical manifestations of primary aldosteronism and confirmed histologically. Adrenal samples were obtained from surgical specimens of 12 APA patients and three patients with renal cell carcinoma without adrenal disease, after obtaining informed consent. Adrenal glands from APA patients were separated into tumor and non-tumor portions after the adrenal medulla was dissected. Nodules surrounding the main tumor were not included in the non-tumor portion. The study was approved by the Ethical Committee of the National Taiwan University Hospital (NCT00173446).

\section{Cell culture}

Primary cultured cells from human normal adrenal cortex (NAC) were prepared from surgical specimens of patients who were free from adrenal disease. The primary NAC culture was prepared as described by Liu et al. (1995). Briefly, small pieces of tissue were washed in Hanks' Balanced Salt Solution and minced in culture medium (DMEM-Ham's F-12 medium containing 10\% FCS, $2 \mathrm{mmol} / \mathrm{l}$ glutamine (Gibco), $1.25 \times 10^{5} \mathrm{IU} / \mathrm{l}$ penicillin, and $0.125 \mathrm{~g} / 1$ streptomycin sulfate (Gibco)). The minced tissues were dissociated with $0.3 \%$ collagenase-IA and $20 \mathrm{mg} / \mathrm{l}$ deoxyribonuclease-I (Sigma-Aldrich Co.) in culture medium at $37^{\circ} \mathrm{C}$. Digestion was carried out over two 2 -h periods. The dispersed cells were washed once with medium and plated on six-well plastic cell culture dishes. The cultures were maintained at $37^{\circ} \mathrm{C}$ in humidified $95 \%$ air at $5 \% \mathrm{CO}_{2}$, with replacement of medium every 3 days until the cells achieved subconfluency on days 5-10 of culture. The NAC cells cultured at this stage expressed both DRD2 and AT1R and preserved the physical function to secrete aldosterone after addition of AII. Ten nanomolar AII (Sigma-Aldrich Co.), $1 \mu \mathrm{mol} / 1$ bromocriptine (BMC) (Sigma-Aldrich Co.), and $1 \mu \mathrm{mol} / 1$ raclopride (Racl) (Sigma-Aldrich Co.) were used in all experiments unless otherwise mentioned. All experiments were performed at least in triplicate; for each experiment, the data analyzed was the mean of three measured samples.

\section{Chemicals}

AII, BMC, Racl, tetrazole 3-(4,5-dimethylthiazol-2-yl-)2,5-diphenyltetrazolium bromide (MTT), and PD98059 were purchased from Sigma-Aldrich Co. and phosphoPKC-specific antibodies, PKC subtype-specific antibodies, and phospho-MAPK-specific antibodies from Cell Signaling Technology, Inc. (Danvers, MA, USA). AT1R (sc1173), P21 (sc817), P27 (sc1641), and P53 (sc71784) were obtained from Santa Cruz Biotechnology, Inc. D2 receptor antibody and its immunizing peptide were from Chemicon (Temecula, CA, USA). Cyclin D1 (NB110-2308) antibody was from Novus Biologicals, Inc. (Littleton, CO, USA).

\section{Immunoblotting}

APA and NAC were separated from surgical specimens and solubilized in lysis buffer. For western blots, equal amounts of protein ( $10 \mu \mathrm{g}$ for human tissue) were separated on a 10\% polyacrylamide gel and were transferred to Immobilon P membranes. Blots were probed with different antibodies, followed by a HRP-conjugated anti-rabbit secondary antibody. Immunoreactive proteins were visualized with enhanced chemiluminescence (Pierce, Rockford, IL, USA).

Published by Bioscientifica Ltd. 


\section{MTT test}

The MTT cell proliferation assay was purchased from the American Tissue Culture Collection (Manassas, VA, USA) and performed according to the manufacturer's instructions. Briefly, NAC or APA cells were incubated in the presence of $0.5 \mathrm{mg} / \mathrm{ml}$ MTT reagent for $4-8 \mathrm{~h}$, after which cells were lysed by the addition of one volume of solubilization solution (40\% dimethylformamide and $10 \%$ SDS, pH 4.0). Absorbance (A) in the wells was read with a microplate reader with a $570 \mathrm{~nm}$ cutoff filter. Viable cells metabolizing MTT were quantified at $570 \mathrm{~nm}$ by spectrophotometer and then translated into the cell number by normalizing the measurement against the $570 \mathrm{~nm}$ absorption of a known number of directly countable viable cells.

\section{Quantitative real-time PCR}

Quantitative real-time PCR was carried out in an Applied Biosystems 7900 Real-Time PCR System using TaqMan gene expression assays for AT1R and DRD2 as described in the user manual (assay ID, Hs00258938_m1 and Hs00241436_m1 respectively). GAPDH (assay ID, Hs99999905_m1) was used as an endogenous control in the TaqMan human endogenous control plate (Applied Biosystems; Volpe et al. 1997). Cycle to threshold (Ct) was recorded for statistical analysis. Sample dilutions contained $100 \mathrm{ng}$ template cDNA. All samples were tested in a total volume of $20 \mu \mathrm{l}$ in triplicate.

\section{Short hairpin RNA (shRNA) for PKC $\mu$}

The sense strand for synthesis of shRNA targeting PKC $\mu$ was CCAGAGCACATAACGAAGTTT. The control plasmid expressing an shRNA against EGFP was purchased from Open Biosystems, Inc. (Huntsville, AL, USA). Lentiviruses carrying the target nucleotides were generated by cotransfecting $9 \mu \mathrm{g}$ lentiviral vector (Plko1), $4.5 \mu \mathrm{g}$ pHCMV-G (envelope system: VSV-G), and $6.75 \mu \mathrm{g}$ of pCMV $\Delta$ R8.2 (packaging vector: env, tat, rev, vpr, vpu, vif, and nef) into 293T cells using calcium phosphate reagent $(2 \times$ BBS $750 \mu \mathrm{l}, 2.5 \mathrm{M} \mathrm{CaCl}_{2} 75 \mu \mathrm{l}$, and $\mathrm{H}_{2} \mathrm{O} 750 \mu \mathrm{l}$ ) (Dull et al. 1998). Supernatants were collected 48 and $72 \mathrm{~h}$ after transfection, filtered through a $0.45 \mu \mathrm{m}$ membrane (Amicon Ultra-15 $100 \mathrm{~K}$, Millipore, Billerica, MA, USA), centrifuged at $4000 \boldsymbol{g}$ for $30 \mathrm{~min}$ at $4{ }^{\circ} \mathrm{C}$, and used to directly infect NAC. The level of PKC $\mu$ was semi-quantified by SDS-PAGE and immunoblotting with a PKC $\mu$-specific antibody. The experiments were carried out $48 \mathrm{~h}$ after infection.

\section{Bromodeoxyuridine assay}

Cell proliferation was determined by bromodeoxyuridine (BrdU) incorporation analysis. NAC cells were plated in 96-well plates (100 cells/well, counted with a hemocytometer). After incubation for $12 \mathrm{~h}$, BrdU was added to the medium for $2 \mathrm{~h}$. (HTS01, Calbiochem EMD Chemicals, Inc., Billerica, CA, USA). Plates were analyzed using a fluorometer at $320 \mathrm{~nm}$ excitation and $460 \mathrm{~nm}$ emission.

\section{Cell apoptosis assay}

DNA fragmentation was detected by an ELISA specific for nucleosome-associated cytosolic DNA. Apoptosis ELISA was performed using the Roche Cell Death Detection ELISA Kit (Roche Diagnostics). This assay is based on the sandwich-enzyme immunoassay principle using mouse MABs directed against DNA and histones respectively. This technique allows the specific determination of mononucleosomes and oligonucleosomes in the cytoplasmic fraction of the cell. Cell lysates isolated as described above were used for ELISA. Sample absorbance was read with a spectrophotometer at a wavelength of $405 \mathrm{~nm}$.

\section{Statistical analysis}

Statistical analysis was performed with the MannWhitney $U$ test using the Stat View Software Package (Abacus Concepts, Inc., Berkeley, CA, USA). Statistical significance was accepted for $P<0.05$. All the statistical analyses were aided by the advice of the statistics specialist of the Graduate Institute of Clinical Medicine, National Taiwan University College of Medicine.

\section{Results}

DRD2 activation attenuated All-induced cell proliferation

Three cell populations of APA and three clones of NAC were obtained from APA and renal cell carcinoma patients respectively. The viability of the cells was assayed using the MTT test at 4, 8, 12, 24, and $48 \mathrm{~h}$ after subculture with 2000 cells in each well of 96 -well plates. The increase in the number of viable cells after $24 \mathrm{~h}$ is illustrated in Fig. 1a. Under all conditions, treated or untreated, the cell numbers for APA were greater than those for NAC $(P<0.01)$. After 24-h culture, the increased cell number for APA was $30 \%$ more than that for NAC cells. AII doubled the cell numbers of both of APA and NAC, but the difference remained 30\%. Treatment with DRD2 agonist (BMC) attenuated the AII-stimulated viable cell number of both NAC and APA $(P<0.005)$. The BMC effect

Published by Bioscientifica Ltd 

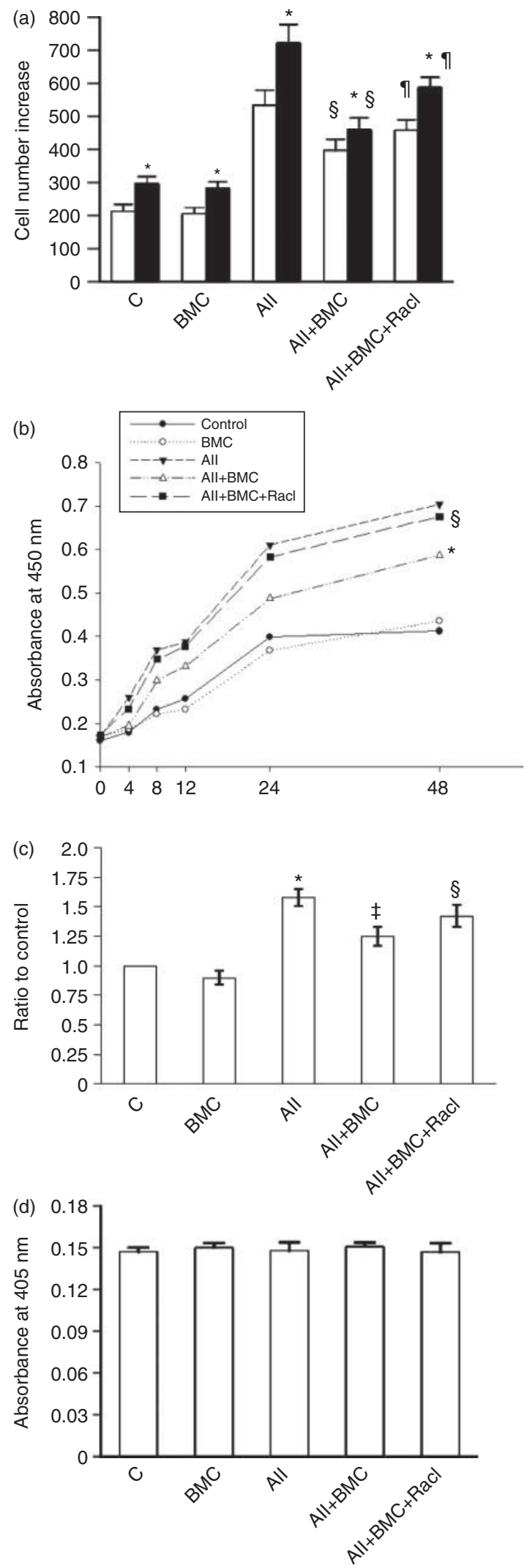

http://jme.endocrinology-journals.org DOI: 10.1530/JME-13-0044 could be partially reversed by DRD2 antagonist (Racl) for both NAC and APA, 12 and 23\% respectively $(P<0.05)$.

Our previous study showed that DRD2 was expressed much less in APA than in the respective non-tumorous adrenal cortex. Whether DRD2 has a role in the regulation of the proliferative adrenal cortical cells should be clarified. Treatment with BMC $(1 \mu \mathrm{mol} / \mathrm{l})$ attenuated the AIIinduced increase in cell number (Fig. 1a and b) but did not alter the basic growth rates for either NAC or APA cells. This attenuating effect of BMC was more obvious in APA than in NAC cells and was partially reversed by treatment with Racl (Fig. 1a and b). The rate of cell proliferation decelerated when cells became confluent (Fig. 1b).

In order to understand whether the increase in the number of viable cells stimulated by AII resulted from increased cell proliferation or decreased cell death, BrdU incorporation was performed to measure the rate of DNA synthesis, which is known to parallel the rate of cell division. Because the significant differences in the numbers of the viable cells were observed by $24 \mathrm{~h}$ after treatment, the cell division rates were measured at $12 \mathrm{~h}$. Treatment with AII significantly enhanced BrdU incorporation of NAC cells; this effect was attenuated by BMC and was partially reversed by adding Racl (Fig. 1c). On the other hand, in the apoptosis experiments, the accumulations of BrdU-incorporated DNA fragments in cell extracts at $24 \mathrm{~h}$ were not affected by the experimental conditions (Fig. 1d); additionally, no differences were observed in the supernatants (data not shown). These results indicate that the effect of BMC on the AII-stimulated increase in cell viability was due to the inhibition of cell proliferation but not the induction of cell apoptosis.

\section{DRD2 level in APA, non-tumorous tissue, and in the NAC}

Consistent with our previous study, the level of DRD2 in APA was much lower than in the respective non-tumorous adrenal cortex or NAC. The levels of AT1R were not different among

\section{Figure 1}

(a) MTT test to quantify cell proliferation in primary cultures of human adrenal cortical cells (blank bar) and APA cells (dark bar) after $24 \mathrm{~h}$ under the five culture conditions: control, $1 \mu \mathrm{M}$ bromocriptine (BMC), $10 \mathrm{nM}$ angiotensin II (All), $10 \mathrm{nM}$ All $+1 \mu \mathrm{M} \mathrm{BMC}$, and $10 \mathrm{nM}$ All $+1 \mu \mathrm{M}$ BMC+ $1 \mu \mathrm{M}$ raclopride (Racl). ${ }^{*} P<0.01$, APA vs NAC; ${ }^{\S} P<0.01$, All + BMC vs All; " $P<0.05$, All + BMC+Racl vs All + BMC. (b) MTT test for the time course of DRD2 activation during cell proliferation in human normal adrenal cortex. ${ }^{*} P<0.01$, All + BMC vs All; ${ }^{\$} P<0.05$, All + BMC+Racl vs All + BMC. (c) Effect of DRD2 activation on DNA synthesis rate assayed by 2-h BrdU incorporation at $24 \mathrm{~h}$ after treatment. *Angll vs control, $P<0.01,{ }^{\ddagger}$ vs All, $P<0.05$, svs All + BMC, $P<0.05$. (d) Effect of DRD2 on cell apoptosis $24 \mathrm{~h}$ after treatment as evaluated by intracellular fragmentation of DNA. All experiments were performed in at least triplicate. 
the three different tissue samples (Fig. 2a). The mRNA expression of DRD2 and AT1R in these three different samples paralleled the findings from western blotting, namely that DRD2 mRNA level was downregulated in APA, and no difference in AT1R mRNA expression was observed, in comparison with the non-tumor portion and NAC (Fig. 2b).

\section{Effect of DRD2 on PKC $\mu$ phosphorylation and cell proliferation}

As demonstrated in our previous study, APA expressed more abundant phosphorylated PKC $\mu$ than the
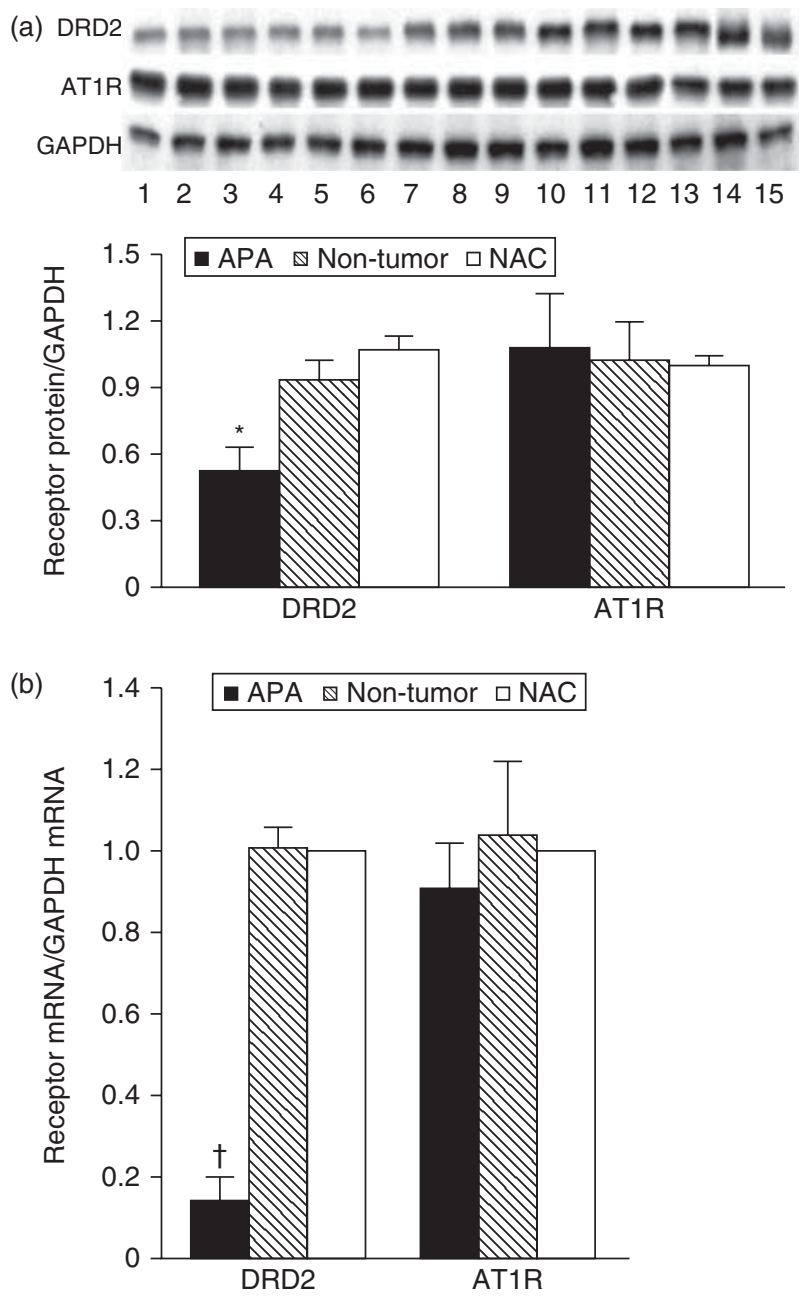

Figure 2

Expression of DRD2 and AT1R in human normal adrenal cortex (NAC), APA, and non-tumorous tissues. (a, Upper panel) DRD2 and AT1R levels determined by immunoblotting. Lanes 1-6, APA; lanes 7-12, corresponding non-tumor tissues; lanes 13-15, NAC; (a, lower panel) quantification by densitometry for DRD2 and AT1R expression, (b) quantification of mRNA expression of DRD2 and AT1R by real-time PCR; NAC served as a reference. $\left({ }^{*} P<0.05,{ }^{\dagger} P<0.01\right.$, APA vs non-tumorous tissues and NAC). All experiments were performed in at least triplicate. non-tumor portion or NAC $(P<0.05$; Fig. 3a). The levels of total PKC $\mu$, total PKC $\alpha$, total PKC $\beta I I$, and phosphorylated PKC $\alpha / \beta I I$ were not different among three types of tissue samples however. In primary cultured cells of NAC, AII increased the phosphorylation of PKC $\mu$ (Ser916), PKC $\mu$ (Ser744/748), PKC $\alpha / \beta I I$, and PKC $\varepsilon$, but not PKC $\theta$ or $\mathrm{PKC} \lambda$. BMC treatment attenuated only the AII-induced PKC $\mu$ (Ser916) phosphorylation, which was reversed by adding Racl (Fig. 3b). Depletion of PKC $\mu$ protein expression in NAC via transfection of targeted shRNA reduced the level of AII-stimulated cell proliferation by over $50 \%$ (Fig. 3c).

\section{DRD2 and MAPK phosphorylation}

There was a higher level of phospho-ERK in APA than in non-tumorous tissue and NAC; however, there was no difference in the levels of phospho-JNK and phospho-p38 among these tissue samples (Fig. 4a).

To investigate whether the anti-proliferative effect of DRD2 is mediated by modification of MAPK activation, the effects of BMC on the phosphorylation of ERK1/2, JNK, and p38 were studied. AII stimulated the phosphorylation of these three molecules, but only the phosphorylation of ERK1/2 was attenuated by BMC (Fig. 4b), more than 30\%. PD98059, an inhibitor of ERK phosphorylation, dose dependently inhibited AII-stimulated cell proliferation (Fig. 4c). This result indicates that the inhibitory effect of DRD2 on AII-induced proliferation of NAC cells was mostly due to the attenuation of ERK phosphorylation. Depletion of PKC $\mu$ reduced AIIstimulated ERK phosphorylation by more than 50\% (Fig. 4d).

\section{Cyclin D1 as a target for All-stimulated cell cycle progression}

AII treatment increased cyclin D1 protein expression in NAC cells, and BMC significantly attenuated it; this effect was reversed by adding Racl (Fig. 5a). Depletion of PKC $\mu$ by infection with lentiviruses $\mathrm{PKC} \mu$ shRNA reduced protein expression of AII-induced cyclin D1 by 30\% (Fig. 5b). Inhibition of ERK phosphorylation by PD98059 also decreased AII-stimulated cyclin D1 protein expression (Fig. 5c).

\section{Discussion}

PKC $\mu$ (PKD) has been proven to play a role in AII-induced aldosterone production (Romero et al. 2006, Shapiroa et al. 2010). In a previous study, we demonstrated that DRD2 inhibits AII-stimulated aldosterone synthesis/ secretion through attenuation of $\mathrm{PKC} \mu$ phosphorylation

Published by Bioscientifica Ltd 
(a)
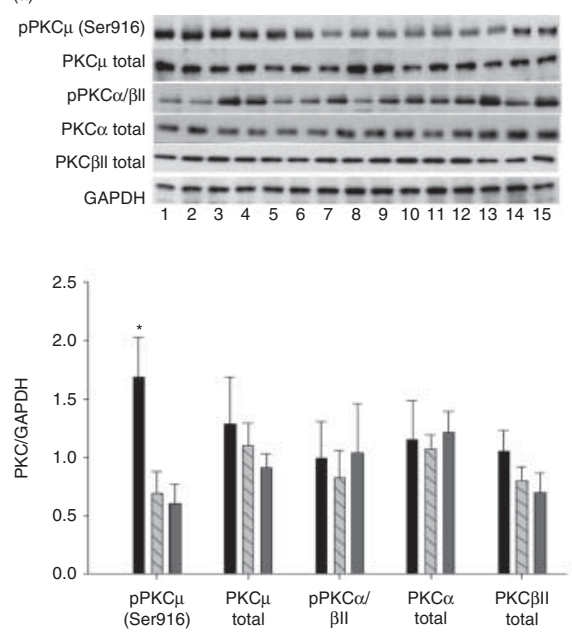

(b)

$$
\begin{array}{r}
\mathrm{pPKC} \mu(\text { Ser916) } \\
\mathrm{pPKC} \mu(\text { Ser744/748) } \\
\mathrm{pPKC} \alpha / \beta \| \text { (Thr638/641) } \\
\mathrm{pPKC} \theta(\text { Thr538) } \\
\mathrm{pPKC} \varepsilon(\text { Ser729) } \\
\mathrm{pPKC} \lambda(\text { Thr410/403) } \\
\text { GAPDH }
\end{array}
$$

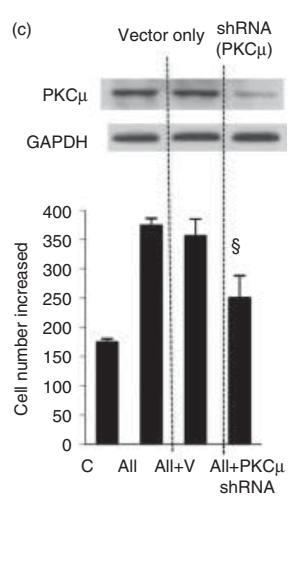

Figure 3

(a, Upper panel) Immunoblotting of phosphorylated PKC isoforms in different tissues, Lanes 1-6, APA; lanes 7-12, corresponding non-tumor tissues; lanes 13-15, NAC; (a, lower panel) quantification the immunoblotting results by densitometry, results for APA (black bars), the corresponding non-tumorous tissue (hatched bars), and human normal adrenal cortex (NAC, gray bars). ${ }^{*} P<0.05$, vs non-tumorous tissues and NAC. (b) Effect of DRD2 activation on All-stimulated PKC phosphorylation

(Chang et al. 2007). In this study, we further found that DRD2 inhibited AII-stimulated proliferation of NAC and APA cells, and that phosphorylation of $\mathrm{PKC} \mu$ was responsible for the signaling mechanism.

In fact, we cannot separate the zona fasciculata (ZF) cells from zona glomerulosa (ZG) cells completely as many previous reports. It is highly possible that some of our cultured cells were ZG cells and some were ZF cells. However, there were over 70\% CD56-positive cells in our primary cultured NAC and APA cells. It has been noted that ZG cells rather than ZF cells expressed CD56 (Caroccia et al. 2010). In addition, the mRNA expressions of CYP11B2 over CYP11B1 were about 6.86 and 8.78 in our primary cultured NAC and APA cells respectively, indicating that most of the cultured cells were ZG cells. In addition, a previous report has shown that AII stimulated cell proliferation of ZG cells rather than ZF or zona reticularis (ZR) cells (Mazocchi et al. 1997). Our experiments demonstrated that a DRD2 agonist did not alter the basal proliferation rate but inhibited AII-stimulated proliferation of adrenal cortical cells (Fig. 1b). Therefore, the inhibitory effect of DRD2 on the cultured adrenal cortical cells should be limited to the AII-stimulated proliferation of ZG cells rather than the ZF cells.

AII-stimulated PKC translocation contributes to the proliferation of cultured human breast epithelial cells

of primary-cultured human adrenal cortical cells. C, control, BMC, $1 \mu \mathrm{M}$ bromocriptine; Racl, $1 \mu \mathrm{M}$ raclopride; All, $10 \mathrm{nM}$ angiotensin II. ${ }^{\dagger} P<0.05$, vs All. (c) Effect of PKC $\mu$ depletion on the proliferation of primary cultured human adrenal cortical cells at $24 \mathrm{~h}$ after treatment; assayed by MTT test. $\mathrm{V}$, vector for expression of shRNA targeting $\mathrm{PKC} \mu,{ }^{\S} P<0.05$, vs All. All experiments have been performed in at least triplicate.

(Greco et al. 2002). AII also stimulates the proliferation of choriocarcinoma cells through the AT1R and its downstream signals, including PKC and MAPK (Ino et al. 2003). The mitogenic response of adrenal glomerulosa cells to AII is mediated via AT1R activation (McEwan et al. 1990, Tian et al. 1995). However, studies analyzing the expression of AT1R in APA have not shown significant differences in AT1R mRNA levels in comparison with non-tumorous tissue (Kitamura et al. 1998, Chang et al. 2007). In our previous study, we found that AII-stimulated $\mathrm{PKC} \alpha / \beta \mathrm{II}, \mathrm{PKC} \varepsilon$, and $\mathrm{PKC} \mu$ phosphorylation and translocation to membrane in human adrenal cortical cells and DRD2 activation only attenuated AII-stimulated PKC $\mu$ phosphorylation and translocation to membrane (Chang et al. 2007). Therefore, the tumorigenesis of APA can be partially attributed to the loss of DRD2 inhibitory tone under concomitant stimulation by AII. An interactive balance between DRD2 and AII signaling appears to underlie the regulation of adrenal cortical cell proliferation.

In this study, we demonstrated that the inhibitory effect of DRD2 on adrenal cortical cell proliferation was mediated by attenuation of PKC $\mu$ phosphorylation. PKC $\mu$ is involved in many physiological functions including cell proliferation, migration, protein transport, survival, and apoptosis (Wang 2006). Over-expression of PKD1, the mouse homolog of $\mathrm{PKC} \mu$, has been noted in mouse skin

Published by Bioscientifica Ltd 
(a)
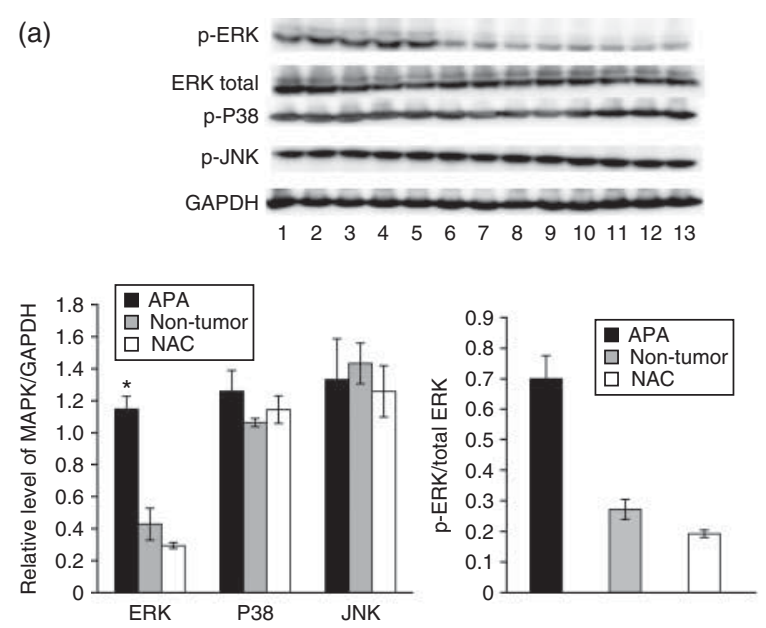

(c)

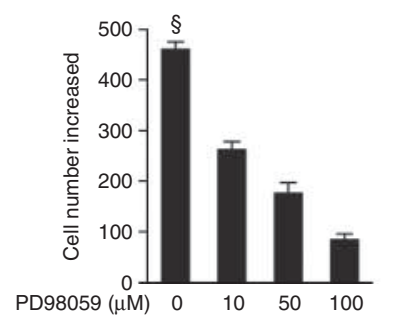

(b)
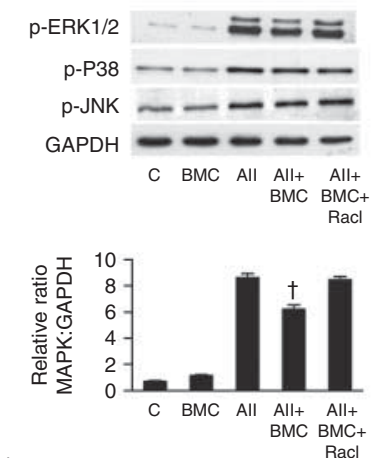

(d)
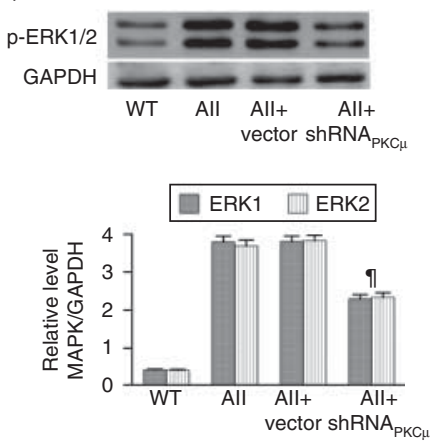

\section{Figure 4}

(a, Upper panel) Immunoblotting of phospho-MAPK expression, lanes 1-5, APA; lanes 6-10, corresponding non-tumor tissues; lanes 11-13, NAC;

(a, lower panel) quantification of the immunoblotting results by densitometry, results for APA (black bars), the corresponding non-tumorous tissue (gray bars), and human normal adrenal cortex (NAC, white bars). ${ }^{*} P<0.05$ vs non-tumor portion and NAC. (b) Immunoblotting of MAPK phosphorylation in primary cultured human adrenal cortical cells 5 min after various

carcinoma (Iaccarino et al. 2002) as well as in basal cell carcinoma and psoriatic skin lesions (Ristich et al. 2006). Inhibition of PKC $\mu$ by Go6976 decreased the proliferation of primary mouse epidermal keratinocytes (Hausser et al. 2001). VEGF-induced angiogenesis of primary human umbilical vein endothelial cells has been shown to require PKC $\mu$ phosphorylation (Rennecke et al. 1999). In Swiss 3 T3 cells, over-expression of PKC $\mu$ potentiates DNA synthesis and cell growth induced by bombesin and vasopressin (Zhukova et al. 2001, Sinnett-Smith et al. 2004). Our study showed a greater level of phosphorylated PKC $\mu$ in tumor areas of APA than in non-tumor areas or in the NAC. The inhibition of AIIstimulated cell proliferation by depletion of $\mathrm{PKC} \mu$ indicates the involvement of PKC $\mu$ in the mitogenesis of adrenal cortical cells. Therefore, the decreased DRD2 level in APA may augment AII-stimulated PKC $\mu$ phosphorylation and in turn contribute to APA tumorigenesis.

ERK1/2 is a signaling molecule that responds to several mitogenic stimuli (Werry et al. 2006, Katz \& Yarden 2007). treatments; C, control; All, $10 \mathrm{nM}$ angiotensin II; BMC, $1 \mu \mathrm{M}$ bromocriptine; Racl, $1 \mu \mathrm{M}$ raclopride. ${ }^{\dagger} P<0.05$ vs All. (c) Dose effect of PD98059 on induction of cell proliferation at $24 \mathrm{~h}$ after All treatment $(10 \mathrm{nM})$ in primary cultured NAC cells; ${ }^{\S} P<0.05$, vs PD98059 treatment (10 nM) (d) Immunoblotting of phospho-ERK $1 / 2$ expression in primary cultured human adrenal cortical cells. WT, vector: the vector for expression of PKC $\mu$ shRNA. ${ }^{\S} P<0.05$, vs All experiments have been performed in at least triplicate.

We demonstrated that AII stimulated the phosphorylation of ERK1/2, JNK, and p38 in human adrenal cortical cells, but only ERK1/2 was modulated by DRD2. The effects of DRD2 on MAPK/ERK activation are controversial. In mouse endothelial cells, dopamine inhibits VEGF-induced phosphorylation of VEGFR2, MAPK, and focal adhesion kinase (Sarkar et al. 2004). However, Iaccarino et al. (2002) observed increased phosphorylation of ERK1/2 in lactotroph cells at $15 \mathrm{~min}$ after addition of BMC, followed by a return to the baseline levels at $16 \mathrm{~h}$. Over-expression of the short variant of DRD2 in mice led to the activation of MAPK and levels of phosphorylated ERKs decreased in DRD2-null mice (Asa et al. 1999). Despite the opposite effect of MAPK activation, ligand activation of DRD2 results in decreased proliferation of lactotroph cells and leads to pituitary hypoplasia (Iaccarino et al. 2002). In addition, ablation of DRD2 resulted in hyperprolactinemia and prolactinomas (Asa et al. 1999). The current study showed that a D2 agonist selectively attenuated

Published by Bioscientifica Ltd. 
(a)
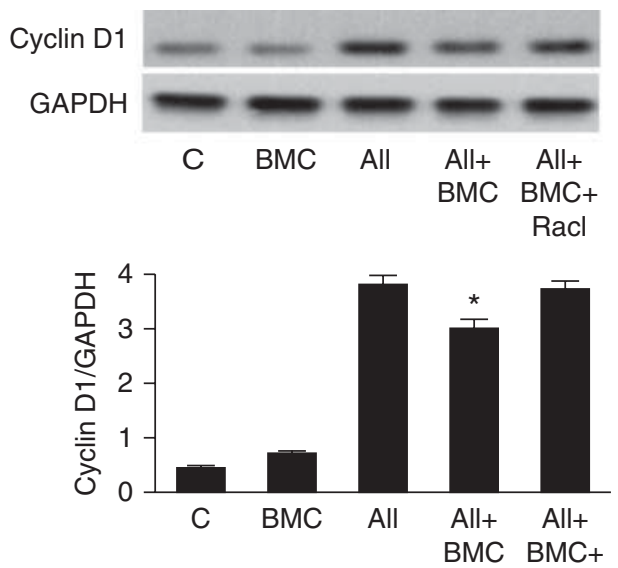

(b)
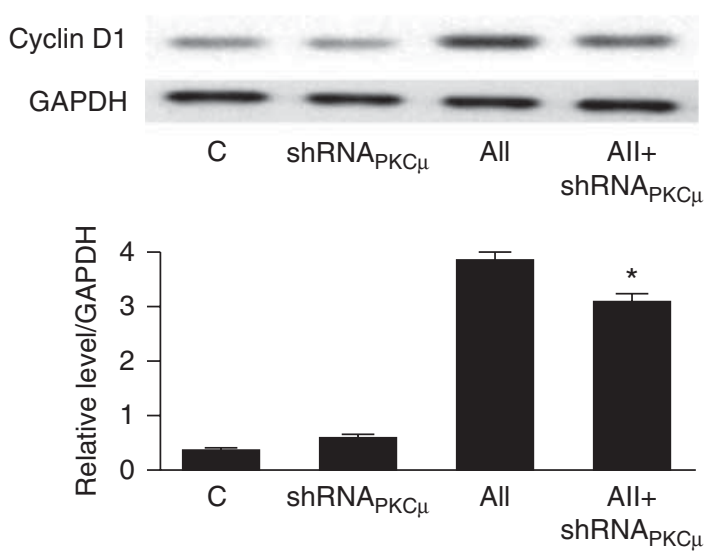

(c)
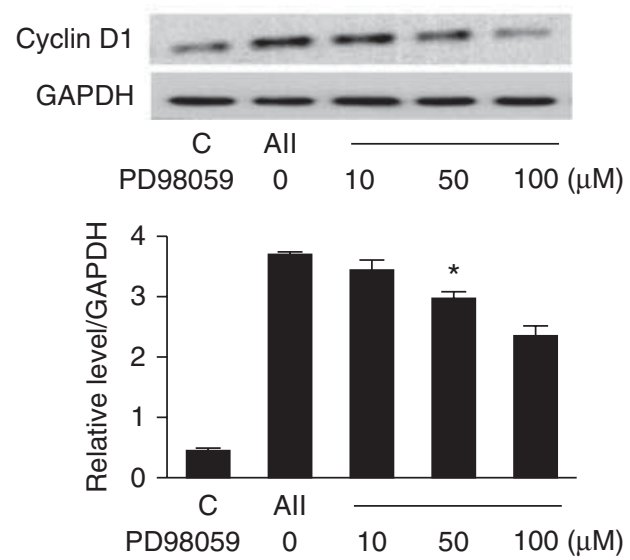

Figure 5

Effects of DRD2 agonist/antagonist (a), depletion of PKC $\mu$ (b), and PD98059 treatment (c) on All-stimulated cyclin D1 expression in primary cultured human adrenal cortical cells. C, control; BMC, $1 \mu \mathrm{M}$ bromocriptine; Racl, $1 \mu \mathrm{M}$ raclopride; All, $10 \mathrm{nM}$ angiotensin II. $* P<0.05$ vs All. All experiments were performed in at least triplicate.

AII-stimulated phosphorylation of ERK1/2 but not JNK and p38 in human adrenal cortical cells. In comparison with NAC, APA showed downregulation of DRD2 that was accompanied by the elevated phosphorylation of $\mathrm{PKC} \mu$ and ERK1/2. Therefore, loss of the inhibitory effect of DRD2 on AII-stimulated PKC $\mu$ and ERK1/2 phosphorylation may play a role in the tumorigenesis of APA.

There is evidence for the relationship between $\mathrm{PKC} \mu$ and ERK1/2. Transient expression of constitutively active PKC $\mu$ led to activation of Raf- 1 kinase and phosphorylation of ERK1 but not of JNK and p38 MAPKs (Hausser et al. 2001). PKC $\mu$ may also mediate endothelial proliferation and ERK activation induced by vascular endothelial growth factor (Wong \& Jin 2005). PKC $\mu$ upregulates Ras activity and ERK1/2 signaling by phosphorylating Ras-binding protein RIN1 to release Ras for subsequent activation in the Raf-MEK-ERK pathway (Lint et al. 1995, Wang et al. 2002). In this context, the anti-proliferative effect of DRD2 in adrenal glomerulosa cells probably resulted from the attenuation of PKC $\mu$ and ERK1/2 phosphorylation.

Some may argue that the rennin-angiotensin system is blunt in primary aldosteronism and therefore the exploration of the role of DRD2 in the proliferogenic response to AII is odd. Although the RAS activity may be lower in PA, the AII-responsive subtype of APA is well documented (Gordon 1995) and characterized by an increase in aldosterone secretion on assuming an upright posture and after ambulation. Our previous study has shown an inverse correlation of DRD2 level in APA with PAC and CYP11B2 mRNA expression. This finding indicates that the different amount of DRD2 may contribute to the heterogeneous sensitivity to AII stimulation in APA (Chang et al. 2007). It is possible that downregulation of DRD2 may increase the sensitivity of the proliferation response to aldosterone-producing cells under the same plasma concentration of AII. As the tumor grew and plasma aldosterone increased, AII decreased in some of these patients, but not all. The reduced AII stimulation slows the tumor growth rate to a steady-state condition. Besides, the AT1R level is not reduced in APA (Chang et al. 2007) and some of APA patients do not have reduced plasma AII levels. Therefore, AII could retain its stimulating effect on the proliferation of these aldosterone-producing cells.

In summary, similar to its inhibition aldosterone synthesis/production, DRD2 also antagonizes the AII proliferating effect of adrenal glomerulosa cells as well as APA. PKC $\mu$ and ERK1/2 are the main signaling pathways mediating this anti-proliferative effect. Our findings provide a new therapeutic target for the medical treatment of human APA and perhaps other types of primary aldosteronism.

Published by Bioscientifica Ltd. 


\section{Declaration of interest}

The authors declare that there is no conflict of interest that could be perceived as prejudicing the impartiality of the research reported.

\section{Funding}

This work was supported by grants from the National Science Council, NSC91-2314-B-002-340, 92-2314-B-002-190, 93-2314-B-002-141 (to K-D W) and the Mrs Hsiu-Chin Lee Kidney Research.

\section{Acknowledgements}

The authors thank C L Chen, PhD, Graduate Institute of Clinical Medicine, National Taiwan University College of Medicine, for her assistance with the statistical analysis. They also thank the staff of the 2nd Core Lab, Department of Medical Research, National Taiwan University Hospital, for their technical support.

\section{References}

Asa SL, Kelly MA, Grandy DK \& Low MJ 1999 Pituitary lactotroph adenomas develop after prolonged lactotroph hyperplasia in dopamine D2 receptor-deficient mice. Endocrinology 140 5348-5355. (doi:10.1210/en.140.11.5348)

Campa D, Zienolddiny S, Lind H, Ryberg D, Skaug V, Canzian F \& Haugen A 2007 Polymorphisms of dopamine receptor/transporter genes and risk of non-small cell lung cancer. Lung Cancer 56 17-23. (doi:10.1016/ j.lungcan.2006.11.007)

Caroccia B, Fassina A, Seccia TM, Recarti C, Petrelli L, Belloni AS, Pelizzo MR \& Rossi GP 2010 Isolation of human adrenocortical aldosteroneproducing cells by a novel immunomagnetic beads method. Endocrinology 151 1375-1380. (doi:10.1210/en.2009-1243)

Chang H-W, Chu T-S, Huang H-Y, Chueh S-C, Wu V-C, Chen Y-M, Hsieh B-S $\&$ Wu K-D 2007 Down-regulation of D2 dopamine receptor and increased protein kinase $\mathrm{C} \mu$ phosphorylation in aldosterone-producing adenoma play roles in aldosterone overproduction. Journal of Clinical Endocrinology and Metabolism 92 863-870. (doi:10.1210/jc.2006-2338)

Dull T, Zufferey R, Kelly M, Mandel RJ, Nguyen M, Trono D \& Naldini L 1998 A third-generation lentivirus vector with a conditional packaging system. Journal of Virology 72 8463-8471.

Gemignani F, Landi S, Moreno V, Gioia-Patricola L, Chabrier A, Guino E, Navarro M, Cambray M, Capellà G, Canzian F et al. 2005 Polymorphisms of the dopamine receptor gene DRD2 and colorectal cancer risk. Cancer Epidemiology, Biomarkers \& Prevention 14 1633-1638. (doi:10.1158/1055-9965.EPI-05-0057)

Gordon R 1995 Primary aldosteronism. Journal of Endocrinological Investigation 18 495-511.

Greco S, Muscella A, Elia MG, Salvatore P, Storelli C \& Marsigliante S 2002 Activation of angiotensin II type I receptor promotes protein kinase $\mathrm{C}$ translocation and cell proliferation in human cultured breast epithelial cells. Journal of Endocrinology 174 205-214. (doi:10.1677/ joe.0.1740205)

Hausser A, Storz P, Hübner S, Braendlin I, Martinez-Moya M, Link G \& Johannes F-J 2001 Protein kinase $C \mu$ selectively activates the mitogenactivated protein kinase (MAPK) p42 pathway. FEBS Letters 492 39-44. (doi:10.1016/S0014-5793(01)02219-0)

Iaccarino C, Samad TA, Mathis C, Kercret H, Picetti R \& Borrelli E 2002 Control of lactotrop proliferation by dopamine: essential role of signaling through D2 receptors and ERKs. PNAS 99 14530-14535. (doi:10.1073/pnas.222319599)

Ino K, Uehara C, Kikkawa F, Kajiyama H, Shibata K, Suzuki T, Khin EE, Ito M, Takeuchi M, Itakura A et al. 2003 Enhancement of aminopeptidase A expression during angiotensin II-induced choriocarcinoma cell proliferation through AT1 receptor involving protein kinase C- and mitogen-activated protein kinase-dependent signaling pathway. Journal of Clinical Endocrinology and Metabolism 88 3973-3982. (doi:10.1210/jc.2002-021582)

Katz M \& Yarden IA 2007 Regulation of MAPKs by growth factors and receptor tyrosine kinases. Biochimica et Biophysica Acta 1773 1161-1176. (doi:10.1016/j.bbamcr.2007.01.002)

Kelly MA, Rubinstein M, Asa SL, Zhang G, Saez C, Bunzow JR, Allen RG, Hnasko R, Ben-Jonathan N, Grandy DK et al. 1997 Pituitary lactotroph hyperplasia and chronic hyperprolactinemia in dopamine D2 receptor-deficient mice. Neuron 19 103-113. (doi:10.1016/ S0896-6273(00)80351-7)

Kitamura Y, Sasamura H, Maruyama T, Nakaya H, Amemiya T, Hayashi M \& Saruta T 1998 Adrenal angiotensin II type 1 and type 2 receptors in Cushing's and Conn's syndromes. Molecular and Cellular Endocrinology 144 37-45. (doi:10.1016/S0303-7207(98)00159-2)

Lint JV, Sinnett-Smith J \& Rozengurt E 1995 Expression and characterization of PKD, a phorbol ester and diacylglycerol-stimulated serine protein kinase. Journal of Biological Chemistry 270 1455-1461. (doi:10.1074/jbc.270.3.1455)

Liu J, Kahri AI, Heikkilä P, Ilvesmäki V \& Voutilainen R 1995 H19 and insulin-like growth factor-II gene expression in adrenal tumors and cultured adrenal cells. Journal of Clinical Endocrinology and Metabolism 80 492-496. (doi:10.1210/jc.80.2.492)

Mazocchi G, Malendowicz LK, Gottardo G, Rebuffat P \& Nussdorfer GG 1997 Angiotensin-II stimulates DNA synthesis in rat adrenal zona glomerulosa cells: receptor subtypes involved and possible signal transduction mechanism. Endocrine Research 23 191-203. (doi:10.3109/ 07435809709031853)

McEwan PE, Vinson GP \& Kenyon CJ 1990 Control of adrenal cell proliferation by $\mathrm{AT}_{1}$ receptors in response to angiotensin II and low-sodium diet. American Journal of Physiology 276 E303-E309.

Otis M, Campbell S, Payet MD \& Gallo-Payet N 2004 Angiotensin II inhibits cell proliferation and stimulates protein synthesis in rat glomerulosa cells. Endocrine Research 30 525-526. (doi:10.1081/ERC-200043615)

Otis M, Campbell S, Payet MD \& Gallo-Payet N 2005 Angiotensin II stimulates protein synthesis and inhibits proliferation in primary cultures of rat adrenal glomerulosa cells. Endocrinology 146 633-642. (doi:10.1210/en.2004-0935)

Rennecke J, Rehberger PA, Fürstenberger G, Johannes F-J, Stöhr M, Marks F \& Richter KH 1999 Protein-kinase-C $\mu$ expression correlates with enhanced keratinocyte proliferation in normal and neoplastic mouse epidermis and in cell culture. International Journal of Cancer 80 98-103. (doi:10. 1002/(SICI)1097-0215(19990105)80:1 < 98::AID-IJC19>3.0.CO;2-D)

Ristich VL, Bowman PH, Dodd ME \& Bollag WB 2006 Protein kinase D distribution in normal human epidermis, basal cell carcinoma and psoriasis. British Journal of Dermatology 154 586-593. (doi:10.1111/ j.1365-2133.2005.07073.x)

Romero DG, Welsh BL, Gomez-Sanchez EP, Yanes LL, Rilli S \& Gomez-Sanchez CE 2006 Angiotensin II-mediated protein kinase D activation stimulates aldosterone and cortisol secretion in H295R human adrenocortical cells. Endocrinology 147 6046-6055. (doi:10. 1210/en.2006-0794)

Rossi GP, Bernini G, Caliumi C, Desideri G, Fabris B, Ferri C, Ganzaroli C, Giacchetti G, Letizia C, Maccario M et al. 2006 A prospective study of the prevalence of primary aldosteronism in 1,125 hypertensive patients. Journal of the American College of Cardiology 48 2293-2300. (doi:10.1016/j.jacc.2006.07.059)

Rykx A, Kimpe LD, Mikhalap S, Vantus T, Seufferlein T, Vandenheede JR \& Lint JV 2003 Protein kinase D: a family affair. FEBS Letters 546 81-86. (doi:10.1016/S0014-5793(03)00487-3)

Saiardi A, Bozzi Y, Baik J-H \& Borrelli E 1997 Antiproliferative role of dopamine: loss of D2 receptors causes hormonal dysfunction and pituitary hyperplasia. Neuron 19 115-126. (doi:10.1016/S08966273(00)80352-9) 
Sarkar C, Chakroborty D, Mitra RB, Banerjee S, Dasgupta PS \& Basu S 2004 Dopamine in vivo inhibits VEGF-induced phosphorylation of VEGFR-2, MAPK, and focal adhesion kinase in endothelial cells. American Journal of Physiology. Heart and Circulatory Physiology 287 H1554-H1560. (doi:10.1152/ajpheart.00272.2004)

Shapiroa BA, Olalaa L, Aruna SN, Parkera PM, Georgea MV \& Bollaga WB 2010 Angiotensin II-activated protein kinase D mediates acute aldosterone secretion. Molecular and Cellular Endocrinology 317 99-105. (doi:10.1016/j.mce.2009.11.017)

Sinnett-Smith J, ZHukova E, Hsieh N, Jiang X \& Rozengurt E 2004 Protein kinase D potentiates DNA synthesis induced by Gq-coupled receptors by increasing the duration of ERK signaling in Swiss 3T3 cells. Journal of Biological Chemistry 279 16883-16893. (doi:10.1074/ jbc.M313225200)

Tian Y, Balla T, Baukal AJ \& Catt KJ 1995 Growth responses to angiotensin II in bovine adrenal glomerulosa cells. American Journal of Physiology 268 E135-E144.

Torpy DJ \& Stratakis CA 1998 Linkage analysis of familial hyperaldosteronism type II - absence of linkage to the gene encoding the angiotensin II receptor type 1. Journal of Clinical Endocrinology and Metabolism 82 611-615. (doi:10.1210/jcem.83.3.4668-10)

Volpe M, Gigante B, Enea I, Porcellini A, Russo R, Lee MA, Magri P, Condorelli G, Savoia C, Lindpaintner K et al. 1997 Role of tissue renin

http://jme.endocrinology-journals.org DOI: 10.1530/JME-13-0044
() 2014 Society for Endocrinology Printed in Great Britain in the regulation of aldosterone biosynthesis in the adrenal cortex of nephrectomized rats. Circulation Research 81 857-864. (doi:10.1161/ 01.RES.81.5.857)

Wang QJ 2006 PKD at the crossroads of DAG and PKC signaling. Trends in Pharmacological Sciences 27 317-323. (doi:10.1016/j.tips.2006. 04.003)

Wang Y, Waldron RT, Dhaka A, Patel A, Riley MM, Rozengurt E \& Colicelli J 2002 The RAS effector RIN1 directly competes with RAF and is regulated by 14-3-3 proteins. Molecular and Cellular Biology 22 916-926. (doi:10.1128/MCB.22.3.916-926.2001)

Werry TD, Christopoulos A \& Sexton PM 2006 Mechanisms of ERK1/2 regulation by seven-transmembrane-domain receptors. Current Pharmaceutical Design 12 1683-1702. (doi:10.2174/ 138161206776873725)

Wong C \& Jin Z-G 2005 Protein kinase C-dependent protein kinase D activation modulates ERK signal pathway and endothelial cell proliferation by vascular endothelial growth factor. Journal of Biological Chemistry 280 33262-33269. (doi:10.1074/jbc.M503198200)

Zhukova E, Sinnett-Smith J \& Rozengurt E 2001 Protein kinase D potentiates DNA synthesis and cell proliferation induced by bombesin, vasopressin, or phorbol esters in Swiss 3T3 cells Journal of Biological Chemistry 276 40298-40305. (doi:10.1074/ jbc.M106512200)

Received in final form 1 November 2013

Accepted 28 November 2013

Accepted Preprint published online 29 November 2013 